\title{
Effect of Employee Commitment on Organizational Performance in Coca Cola Nigeria Limited Maiduguri, Borno State
}

\author{
${ }^{1}$ Peace Irefin, ${ }^{2}$ Mohammed Ali Mechanic \\ ${ }^{1,2}$ (Department of Sociology \& Anthropology) University of Maiduguri
}

\begin{abstract}
This paper examines the Effect of Employee Commitment on Organizational Performance with special interest in Coca Cola Nigeria Limited. Much of the interest in analysing employee commitment stems from concern for the behavioural consequences that are hypothesised to result from it. This paper focuses on the influence of employee commitment on Organisational Performance and Employees' turnover. Both descriptive and explanatory research methodologies were adopted in this study. A five point numerically scaled Likert-Type questionnaire was constructed and administered among selected Staff of Coca Cola Nigeria Limited. The research hypotheses were tested using the Pearson Correlation Coefficient. The result shows that: the level of employee commitment of the Staff of Coca Cola Company Plc is very high; there is a fairly high relationship between employee commitment and organizational performance ; there is also a very high relationship between employee commitment and employees' turnover etc. Some of the recommendations made are that: the management should hire employees who are likely to become linked to the organization; management should create clear and realistic job and organizational previews.
\end{abstract}

\section{Background Of The Study}

Organizations value commitment among their employees because it is typically assumed to reduce withdrawal behaviour, such as lateness, absenteeism and turnover. Hence, there is no doubt that these values appear to have potentially serious consequences for overall organizational performance. The study of employee commitment is important because; a Lo (2009) noted that employees with sense of employee commitment are less likely to engage in withdrawal behaviour and more willing to accept change. Hence, there is no doubt that these values appear to have potentially serious consequences for a core of committed individuals who are the source of organizational life; (b). Workers who become less committed to an organization, will route their commitment in other directions; thus, it is important to know how to develop the right type and level of employee commitment to ensure that the better employees are retained; (c). Employees who develop a high level of employee commitment tend to be highly satisfied and are fulfilled by their jobs; (d). In the current global economic scenario, organizational change is a continuous process that requires support of all employees in the hierarchical structure.

Most organizations have realized that the performance of their workers plays a vital role in determining the success of the organization (Zheng, 2010; Ajila and Awonusi, 2004). As such, it is important for employers and managers alike to know how to get the best of their workers. One of the antecedent determinants of workers' performance is believed to be employee commitment (Ali, 2010; Ajila and Awonusi, 2004). As such, it is important for employers and managers alike to know how to get the best of their workers.

Employee commitment has become one of the most popular work attitudes studied by practitioners and researchers. Akintayo (2010) and Tumwesigye (2010) noted that one of the reasons why commitment has attracted research attention is that organization depend on committed employees to create and maintain competitive advantage and achieve superior performance.

Commitment employees who are highly motivated to contribute their time and energy to the pursuit of organizational goals are increasingly acknowledged to be the primary asset available to an organization (Hunjra, 2010). They provide the intellectual capital that, for many organizations, has become their most critical asset (Hunjra, 2010). Furthermore, employees who share a commitment to the organization and their collective wellbeing are more suitable to generate the social capital that facilitates organizational learning.

It is therefore important for organization to know the aspects that play important role or have big impact in boosting the commitment of their employees. Several factors had been identified in the literature as determinants of employee commitment. Some of the identified factors include; leadership style (Lo, 2009); organizational fairness (Ponnu and Chuah, 2010); corporate social responsibility (Ali et al, 2010) etc. However, most of the past studies on employee commitment were not related to Nigerian business environment. Some of the findings of these studies may not be applicable to Nigeria. As such, it is pertinent to examine the role of employee commitment in achieving organizational performance in the context of Nigeria. 


\subsection{Statement Of The Problem}

Employers are sometimes baffled when their highly-rated employees under-perform and others resign and leave the organization. Management fail to understand why some employees are not committed to the organization even though they have proactively implemented fair compensation policies and human resource (HR) practices to motivate and retain them. It can be costly if employees are not committed in their jobs, and if they lack the motivation to exercise their full potentials.

\subsection{Objectives Of The Study}

The general objective of this study is to examine employee commitment in the Nigerian Business Environment using Coca Cola Maiduguri as a Case Study.

The specific objectives of the study are as follows, to:

i. investigate the impact of employee commitment on organizational performance;

ii. examine the relationship between employee commitment and employees turnover;

iii. examine the dimensions of employee commitment;

\subsection{Research Hypotheses}

Hypothesis I

Based on the research questions, the following hypotheses was tested during the course of the study:

$\mathrm{H}_{0}$ : That employee commitment does not enhance organizational performance.

$\mathrm{H}_{1}$ : That employee commitment enhances organizational performance.

\section{Hypothesis II}

$\mathrm{H}_{\mathrm{o}}$ : That employee commitment does not reduce employees' turnover.

$\mathrm{H}_{1}$ : That employee commitment reduces employees' turnover.

\section{Literature Review}

This section considers the current literature which deals with employee commitment and workers' performance. Although, many of the studies reviewed did not address the employee commitment among Nigerian workers directly, their findings are considered applicable to the Nigerian scenario.

\subsection{Definitions Of Employee Commitment}

According to Akintayo (2010) employee commitment can be defined as the degree to which the employee feels devoted to their organization. Ongori (2007) described employee commitment as an affective response to the whole organization and the degree of attachment or loyalty employees feel towards the organization.

Zheng, (2010) describes employee commitment as simply employees' attitude to organization. This definition of employee commitment is broad in the sense that employees' attitude encompasses various components.

\subsection{Employee Commitment And Workers Performance}

Employee commitment seems to be a crucial factor in achieving organizational success. Individuals with low levels of commitment will do only enough to work by. They do not put their hearts into the work and mission of the organization. They seem to be more concerned with personal success than with the success of the organization as a whole. People who are less committed are also more likely to look at themselves as outsiders and not as long - term members of the organization. An attractive job offer elsewhere is very likely to result in their departure. By contrast, employees with high commitment to an organization see themselves as an integral part of the organization. Anything that threatens the organization is an imminent danger to them as well. Such employees become creatively involved in the organisations mission and values, and constantly think about ways to do their jobs better. In essence, committed employees work for the organization as if the organization belongs to them.

The relationship between employee commitment and workers' performance has been studied under various disguise. Khan, (2010) investigated the impact of employee commitment (Affective commitment, Continuance commitment and Normative commitment) on employee job performance from a sample of 153 public and private and public sector employees of oil and gas sector in Pakistan. The results revealed a positive relationship between employee commitment and employees' job performance. Therefore, job performance emerged as a determinant of employee commitment. Thus, Khan, (2010) advised managers to pay special attention to antecedents of employee commitment and all the factors which foster employee commitment so as to increased employee performance and subsequently increase organizational productivity.

Habib, (2010) investigated the interdependency of job satisfaction and job performance, effect of employee commitment and attitude towards work on performance using a survey data collected from 310 
employees of 15 advertising agencies of Islamabad (Pakistan). They found that employees having greater employee commitment perform well and employees having good attitude towards work are highly satisfied as compared to employees who are less inclined towards their work.

Ali, (2010) found that there is positive relationship between corporate social responsibility and employee commitment as well as between employee commitment and organizational performance. They therefore concluded that organizations can improve their performance through employees' commitment by engaging in social activities since such activities also include the welfare of employees and their families.

\subsection{Determinants Of Employee Commiment}

Numerous factors have been found to inspire commitment. For instance, Ongori (2007) opines that the degree to which employees are committed or loyal to their organization depends largely on job enrichment, employee empowerment and compensation. Camilleri (2002) investigated some of the major antecedents that contribute in making employees committed to an organisation using regression method and analysis of variance and found that education level, personality and position are significance that determine an individual's level of employee commitment. His findings further revealed that education level and position are significantly stronger for the continuance and normative dimensions of employee commitment while personality is significantly stronger for the continuance and effective dimensions.

Dex and Smith (2001) applied OLS regression of the log commitment scale, a range of covariates using data from the 1998 Workplace Employee Relations Survey (WERS) conducted in British establishments from October 1997 to June 1998 to model the determinants of the extent of employees' normative or affective commitment to their employer and found that access to some family - friendly policies such as child care and working at home, improved employees' commitment in the private sector but not in the public sector. Their findings also showed that where employees, but not the employer, thought the organisation had a caring ethos is an important determinant of increased employee commitment. This implies that employees' commitment is largely determined by the organizational culture, especially towards their family welfare, of the company which they work for and not by the attitude of their employer or supervisor towards them.

Lo (2009) examined the relationship between leadership styles (focusing mainly on transformational and transactional leadership styles) and employees' employee commitment in Malaysia using regression analysis and found that transformational leaders are more able to bring in commitment in employees than transactional leaders. Their finding indicates that transformational leaders have a more significant and stronger relationship with employee commitment. This implies that the leaders who give advices, supports, and pay attention to the individual needs of followers will enhance the level of employee commitment of the employees.

Avolio, (2004) examined the linkage between transformational leadership and employee commitment by focusing on psychological empowerment and structural distance using a sample of 520 staffs nurses employed by a large public hospital in Singapore. Their findings showed that there is a positive association between transformational leadership and employee commitment revealing that psychological empowerment medicated the relationship between transformational leadership and employee commitment.

Shastri, (2010) examined the relationship between charismatic leadership and employee commitment in Indian organization with a sample of 147 employees from Eastern and Northern India and found that the two major antecedents (Charismatic leadership and job satisfaction) exert strong effect on employee commitment of the employees of Indian organization in the study sample. This finding indicates that people tend to be more satisfied if their leader displays charismatic behaviour which makes them to be more committed to their organization. Since it was found that leader's sensitivity to member's needs is related to employee commitment, then managers need to be clear about the goals and values of the organization so as to align them with the needs of the workers. This will help to reduce the high turnover rates being experienced in today's Industrial World.

Akintayo (2010) investigated the impact of work-family role conflict on employee commitment of Industrial Workers in Nigeria using linear regression analysis and t-test and found that there was a significant but negative contribution of work-family role conflict to employee commitment. Based on this finding, Akintayo(2010) recommended that organizational support programme needs to be introduced and provided for all levels of workers in order to reduce the burden of work-family role conflict interface and virtually induced commitment to their jobs. He further stated that the level of family responsibilities of the workers need to be considered during recruitment, in assigning responsibilities and placement process in order to foster employee commitment.

\subsection{Theoretical Framework}

\subsubsection{The Side-Bet Period}

The primal thinking is based on Howard Becker's (1960) conception that defined employee commitment as the side-bet theory. This approach was one of the earliest attempts to study a comprehensive 
conceptual framework about employee commitment from perspective on the individual's relationship with the organization.

According to Becker's theory, the relationship between employee and organization are based on the "contract" of economic exchange behaviour, committed employees are committed because they have totally hidden or somewhat hidden investments, "side-bets," they have made by remaining in a given organization. If someone left, the investments of "side-bet" will be claimed hardly. The term "side-bets" refers to the accumulation of investments valued by the individual. Becker (1960) argued that over a period of time certain costs accrue that make it more difficult for the person to disengage from a consistent pattern of activity, namely, maintaining membership in the organization.

Becker's approach claimed that a close connection between employee commitment and employees' voluntary turnover behaviour exist. In fact, it identifies employee commitment as a major predictor in the explanation of voluntary turnover. This contention was supported by later research that followed Becker's theory. According to these studies, commitment should be measured by evaluating the reasons, if any, that would cause a person to leave his organization.

While the side-bet theory was abandoned as a leading commitment theory, the close relationship between employee commitment and turnover as advanced by Becker affected most of the later conceptualization of commitment and established turnover as the main behaviour that should be affected by employee commitment. The influence of the side-bet approach is evident in Meyer and Allen's Scale (1991), which might be named as the continuance commitment. This scale was advanced as a tool for the better testing of the side-bet approach and is one of the three dimensions of employee commitment outlined by Meyer and Allen (1991).

\subsubsection{Middle Affective-Dependence Period}

Second period of employee commitment was advanced by Porter et al. (1974). The focus of commitment shifted from tangible side-bets to the psychological attachment one had to the organization. The affective dependence school attempted to describe commitment as a kind of attitude-centered but "economiccontract". Employee's retention does not only come from economic factors but also affective influence and the later maybe more significant. Accordingly, commitment was defined by Porter and his followers as "...the relative strength of an individual's identification with and involvement in a particular organization..." (Mowday, Steers and Porter, 1979). Then they claimed employee commitment was combined with three parts: "Strong Acceptance", "Participation" and "Loyalty". The exchange theory was established as the main explanation for the process of commitment (Mowday, Porter and Steers, 1982). They advanced commitment as an alternative construct to job satisfaction and argued that commitment can sometimes predict turnover better than job satisfaction.

Commitment was characterized by 3 related factors (Mowday, 1979):

a. A strong belief in and acceptance of the organization's goals and values.

b. A willingness to exert considerable effort on behalf of the organization.

c. A strong desire to maintain membership in the organization.

However, although Porter and his colleagues had contributed for commitment's evolution, they still continued with one of the basic assumptions of Becker's theory, namely, the strong ties between commitment and turnover and following the one dimensional guidance.

Based on the approach of Porter, Steers, Mowday, Boulian operated the famous OCQ (Employee Commitment Questionnaire) which combined 15 items. It followed the three dimensional definition and met satisfied reliability. In addition to the items that reflect the attitudinal notion of commitment, the OCQ included items that refer to what O'Reilly and Chatman (1986) termed the consequences of commitment. Critics of the OCQ would argue that some of the items of the scale deal with turnover intentions or with performance intentions and that all of the statements are more reflective of behavioural intentions than attitudes (O'Reilly and Chatman, 1986).

To overcome the limitation of OCQ, O'Reilly and Chatman (1986), Meyer and Allen (1984) extend it into multi-dimension model respectively. Due to the criticism of the scale, whether justifiable or not, the need for an alternative to the OCQ became evident, with the call coming from two sources. One of them was the O'Reilly and Chatman (1986) approach hat was specifically advanced as a conceptual and operational alternative to the OCQ. The second one, which of Meyer and Allen (1984), started first as a methodological paper aimed at an improved examination of the side-bet approach using scales more appropriate for this goal

\subsection{Research Design}

\section{Research Methodology}

Explanatory research design was adopted in this study. As such, a research survey was undertaken among selected Staff of Coca Cola Nigeria Limited which is the Franchise owners of Coca-Cola and other drinks from the stable of the Nigerian Bottling Company Plc. 


\subsection{Population Of Study}

A total of one hundred (120) respondents were selected for the survey. The sampling technique used was stratified random sampling. Data were obtained from respondents from each Cadre of the Organizational Structure consisting of Junior Staff, Middle-Cadre Staff, Senior Staff, and Management Cadre using a simple random technique to select respondents from each stratum (Cadre). A total of a hundred and twenty(120) questionnaires were distributed out of a hundred (100) were retrieved

\subsection{Research Instrument}

The research instrument used for this study was questionnaire designed by the researcher. The questionnaire was divided into two sections. The first section seeks to obtain the personal information of the respondents while the second section contains the questions that relate to the subject matte

The questionnaire, administered by the respondents, contained twenty (20) items, which sought information from the respondents based on the research questions that were stated earlier. The questionnaire contains only close-ended questions and was as simple as possible so that the respondents could supply the appropriate answer to each question

\subsection{Data Analysis Technique}

The responses to the questions on the questionnaire were analysed using frequency tables, charts, and simple percentage method. The research hypotheses stated earlier were tested using the Pearson Correlation Coefficient to determine the strength, direction and statistical significance of correlation

\section{Analysis of General Characteristics Of Respondents}

Table 4.2.1: Distribution of Respondents by Sex

\begin{tabular}{|l|l|l|}
\hline Sex & Frequency & Percentage (\%) \\
\hline Male & 62 & 62 \\
\hline Female & 38 & 38 \\
\hline Total & $\mathbf{1 0 0}$ & $\mathbf{1 0 0}$ \\
\hline
\end{tabular}

Source: Field Survey, 2012.

Chart 4.2.1: Percentage Distribution of Respondents by Sex

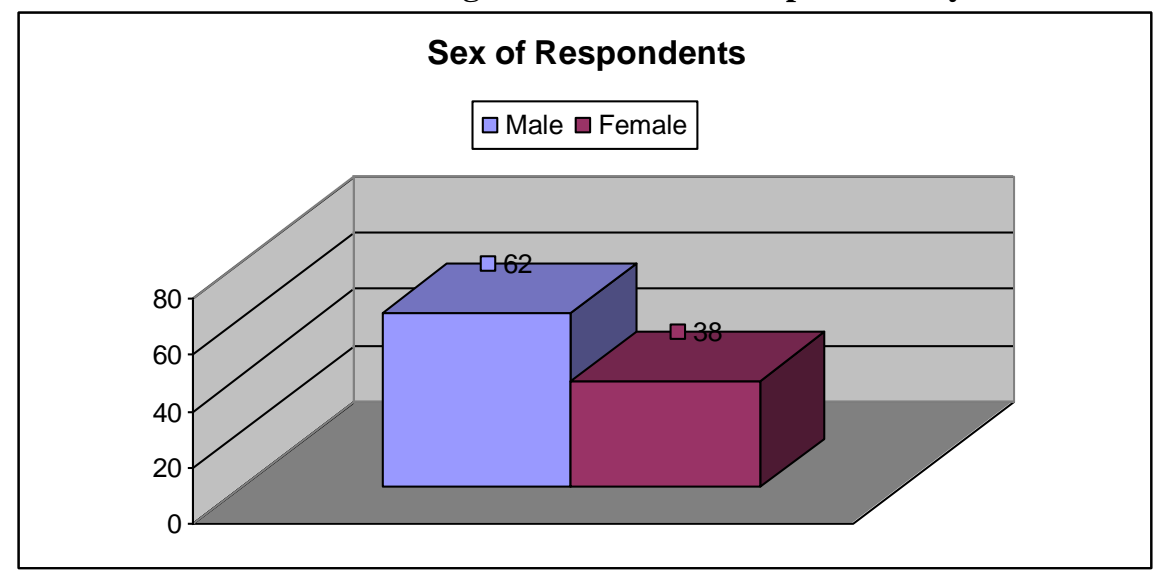

Source: Field Survey, 2012.

Table 4.2.1 and chart 4.2.1 above shows that the male respondents represent $62 \%$ of the total respondents, while $38 \%$ of the respondents are female. It could be deduced from this simple fact that higher percentage of the Staff of Coca Cola Nigeria Limited is male.

Table 4.2.2: Distribution of Respondents by Age.

\begin{tabular}{|l|l|l|}
\hline Age & Frequency & Percentage (\%) \\
\hline Under 20 years & 0 & 0 \\
\hline $21-30$ years & 38 & 38 \\
\hline $31-40$ years & 43 & 43 \\
\hline $41-50$ years & 9 & 9 \\
\hline $51-60$ years & 3 & 3 \\
\hline Above 60 years & 1 & 1 \\
\hline Total & $\mathbf{1 0 0}$ & $\mathbf{1 0 0}$ \\
\hline
\end{tabular}

Source: Field Survey, 2012. 
Table 4.2.2 and chart 4.2.2 above show that majority (43\%) of the respondents are between the ages of 31 and 40 years, then followed by the respondents that are between the ages of 21 and 30 years-38\%. This was followed by $9 \%$ for the respondents that are between the ages of 41 and 50 years while only $1 \%$ of the respondents are above 60 years. None of the respondents is below the age of 20 years. It could be deduced from the result that the ages between 31 and 40 years and between 21 and 30 years are mostly employed by Coca Cola Nigeria Limited probably because of their youthfulness and agility. The applicants between the ages of 21 and 30 and those between 31 and 40 are employers' favourites because they are still very active and interested in building a strong foundation for their career.

Table4.2.3: Distribution of Respondents by Educational/Professional

\begin{tabular}{|l|l|l|}
\hline Educational Qualification & Frequency & Percentage $(\boldsymbol{\%})$ \\
\hline First school leaving certificate & 0 & 0 \\
\hline O' Level/Diploma Certificate & 11 & 11 \\
\hline A' Level/OND/NCE & 49 & 49 \\
\hline HND/First Degree & 2 & 2 \\
\hline Postgraduate Degree & 4 & 4 \\
\hline Professional Qualification & - & - \\
\hline Total & $\mathbf{1 0 0}$ & $\mathbf{1 0 0}$ \\
\hline
\end{tabular}

Source: Field Survey, 2012.

Table 4.2.3 and chart 4.2.3 show that majority of the respondents had HND/University first degree i.e. $49 \%$ followed by A' Level/OND/NCE Holders i.e. 34\%; then Secondary School Certificate/Diploma Certificate Holders i.e. $11 \%, 4 \%$ and $2 \%$ of the respondents are professional qualification holders and postgraduate degree holders respectively. None of the respondents is a primary school leaver. Since the lowest educational qualification of the respondents is O' Level/Diploma Certificate, it is an indication that an average Staff of Coca Cola Nigeria Limited is educated.

Table 4.2.4: Distribution of Respondents by Position

\begin{tabular}{|l|l|l|}
\hline Position Held & Frequency & Percentage (\%) \\
\hline Junior Staff & 57 & 57 \\
\hline Middle Level Officer & 36 & 36 \\
\hline Senior Staff & 6 & 6 \\
\hline Manager & 1 & 1 \\
\hline Management Cadre & 0 & 0 \\
\hline Total & $\mathbf{1 0 0}$ & $\mathbf{1 0 0}$ \\
\hline
\end{tabular}

Source: Field Survey, 2012.

The information presented in the above table and chart below that more than half of the respondents to the questionnaire are Junior Staffs-57\%, followed by the Middle Level Officer (36\%). 6\% of the respondents are Senior Staff of the company while $1 \%$ of the respondents are managers in the company. None of the respondents is in the management cadre.

Table 4.2.5: Distribution of Respondents by Years of Experience

\begin{tabular}{|l|l|l|}
\hline Length of Service & Frequency & Percentage (\%) \\
\hline Below 5 years & 51 & 51 \\
\hline 6-10 years & 28 & 28 \\
\hline $11-15$ years & 14 & 14 \\
\hline Above 15 years & 2 & 2 \\
\hline Total & 100 & 100 \\
\hline
\end{tabular}

Source: Field Survey, 2012.

From the questionnaire collected, which is presented in table 4.2.5 and chart 4.2 .5 above, more than half of the respondents (51\%) have spent between 6 and 10 years in the company. 14\% of the respondents have spent between 11 and 15 years in the company while only $2 \%$ of the respondents has spent more than $15 y e a r s$ with the company. It is evident from the above information that majority of the respondents have not spent much time in the company. 


\subsection{Presentation of Descriptive Statistics}

Table 4.3.1: Mean Distribution of Responses to questionnaire Statements

\begin{tabular}{|l|l|l|}
\hline & \multicolumn{1}{|c|}{ Questionnaire Statements } & Mean \\
\hline Q6 & I feel myself to be a part of this organization & 1.85 \\
\hline Q7 & I am quite proud to be able to tell people the company & 1.81 \\
\hline Q8 & $\begin{array}{l}\text { The offer of a little more money with another company would not seriously make me } \\
\text { think of changing jobs }\end{array}$ & 2.68 \\
\hline Q9 & I would recommend a close friend to join this company & 2.01 \\
\hline Q10 & $\begin{array}{l}\text { To know that my own work has made a contribution to the good of the organization } \\
\text { would please me. }\end{array}$ & 1.84 \\
\hline Q11 & $\begin{array}{l}\text { In my work, I like to feel that I am making some contribution, not for myself but for the } \\
\text { organization as well. }\end{array}$ & 2.13 \\
\hline Q12 & I sometimes feel like leaving this company for good & 2.35 \\
\hline Q13 & $\begin{array}{l}\text { I am not willing to do more than my job description requires just to help the } \\
\text { organization. }\end{array}$ & 2.27 \\
\hline Q14 & $\begin{array}{l}\text { Even if the company were not doing well financially, I would be reluctant to change to } \\
\text { another company. }\end{array}$ & 2.74 \\
\hline Q15 & Working hard leads to good performance & 1.73 \\
\hline Q16 & Working hard leads to high productivity & 1.63 \\
\hline Q17 & Working hard leads to doing my job well & 1.78 \\
\hline Q18 & Generally speaking, I am very satisfied with this job & 1.84 \\
\hline Q19 & I am generally satisfied with the kind of work I do in this job. & 2.36 \\
\hline Q20 & I frequently think of quitting this job & \\
\hline
\end{tabular}

Source: Computed by Author using SPSS.

Table 4.3.2: Results of Correlation Between Employee Commitment and Organizational Performance

\begin{tabular}{|l|l|l|l|}
\hline & & Employment Commitment & $\begin{array}{l}\text { Organizational } \\
\text { Performance }\end{array}$ \\
\hline Employee & $\begin{array}{l}\text { Pearson Correlation } \\
\text { Sign. (1-tailed) }\end{array}$ & 0.782 \\
\hline Organizational Performance & $\begin{array}{l}\text { Pearson Correlation Sig.(1- } \\
\text { tailed) }\end{array}$ & 0.782 & 1.000 \\
0.214 & 1.000 \\
\hline
\end{tabular}

Source: Computed by Author using SPSS.

Table 4.3.3: Results of Correlation Between Employee Commitment and Employees' Turnover

\begin{tabular}{|l|l|l|l|}
\hline & & Employment Commitment & $\begin{array}{l}\text { Organizational } \\
\text { Performance }\end{array}$ \\
\hline Employee & $\begin{array}{l}\text { Pearson Correlation } \\
\text { Sig. (1-tailed) }\end{array}$ & $0.992^{*}$ \\
\hline Organizational Performance & $\begin{array}{l}\text { Pearson Correlation Sig.(1- } \\
\text { tailed) }\end{array}$ & $\begin{array}{l}0.992 * \\
0.041\end{array}$ & 1.000 \\
\hline
\end{tabular}

Source: Computed by Author Using SPSS.

*Correlation is significant at the 0.05 level (1-tailed).

\subsection{Interpretation of Results}

The descriptive statistics of the responses presented in the tables above are quite informative. The main information collected from the respondents through the questionnaire are: their level of commitment to the company, their intent of leaving the company, and their perception of performance. Table 4.3.1, which shows the mean distribution of the responses to main statements on the questionnaire, gives an insight into the general perception of the respondents on each of the main constructs i.e. employee commitment, employees' turnover and organizational performance.

The mean of the responses to all the statements that relate to organization commitment (question 6 and 14) are very high with most of them above the 2.0 mark. This suggest that the workers of the company are to some extent concerned about the performance of the company. This is an affirmation of their commitment to the organization. The mean of the responses to the statements that relate to employees' turnover (question 18 to 20) are also fairly high suggesting that majority of the workers of the company are generally satisfied with their jobs and therefore, they do not intend to leave the company.

The main focus of this study is an investigation of the relationship between employee commitment and organizational performance as well as employee turnover. The first hypothesis testing examines that relationship between employee commitment and organizational performance while the second hypothesis tested the relationship between employee commitment and employees' turnover. Both hypotheses testing were conducting using Pearson Correlation and the results are presented in table 4.3.2 and 4.3.3 respectively. The Pearson Correlation Coefficient for the relationship between employee commitment and organizational performance for on-tail test is 0.782 . This result indicates that there is a fairly high relationship between employee commitment and organizational performance in Coca Cola Company Plc. Therefore, the null hypothesis is rejected while the 
alternative hypothesis is accepted. This implies that employee commitment improves the organization's performance. This result supports the finding of Khan et al (2010) who also found a positive relationship between employee commitment and employees' job performance. It could be deduced from this finding that organizational performance can simply be improved through employee commitment.

The result of the second hypothesis testing shows that the Pearson Correlation Coefficient for the relationship between employee commitment and employees' turnover for on-tail test is 0.992 . This result shows that there is a very high relationship between employee commitment and employees' turnover. Therefore, the null hypothesis is rejected while the alternative hypothesis is accepted. This suggests that there is a significant relationship employee commitment and employees' turnover. This means that employees' turnover rate is highly determined by the level of employee commitment of the workers. This result is in agreement with the findings of Tumwesigye (2010), which revealed that employee commitment is important in the turnover process.

\section{Conclusion And Recommendations}

The major findings of the study are highlighted below:

i. It was found that the level of employee commitment of the Staff of Coca-Cola Company Plc is very high. Although the reason for this is not known, it may not be unconnected to the job security which the workers of the company enjoy;

ii. It was also found that the workers of the company are, to some extent, concerned about the performance of the company. This is an affirmation of their commitment to the company.

iii. The analyses further revealed that majority of the workers of the company are generally satisfied with their jobs and therefore, they do not intend to leave the company;

iv. The result of the first hypothesis testing showed that there is a fairly high relationship between employee commitment and organizational performance in Cocoa-Cola Company Plc.

v. Lastly, the result of the second hypothesis testing revealed that there is a very high relationship between employee commitment and employees' turnover. This means that employees' turnover rate is highly determined by the level of employee commitment of the workers. CONCLUSION

The empirical results indicate that there is a fairly high relationship between employee commitment and organizational performance in Coca Cola Company Plc implying that employee commitment improves the company's performance. It was therefore deduced that organizational performance can simply be improved through employee commitment. It was also found that there is a very high relationship between employee commitment and employees' turnover meaning that employees' turnover rate is highly determined by the level of employee commitment of the workers.

Examinations of the relationship between employee commitment and performance have a long history in organizational studies, mostly at the individual level of analysis and mostly in cross-sectional studies, yet the debate concerning productive worker continues to this day. It is interesting to note that when we move from the individual to the organizational level of analysis, the same questions arise: Are companies with committed workers more productive? Researchers have predicted that the relationship between employee attitudes and organizational performance is complex, and it is too simplistic to assume that satisfaction attitudes lead to improved organizational performance-some do and some do not, and some employee attitudes apparently are the result of organizations' culture.

\subsection{Recommendations}

Based on the findings, the following recommendations are hereby suggested:

Since it was found that there is a fairly high relationship between employee commitment and organizational performance, the management of companies are advised to hire employees who are likely to become linked to the organization. Before they hire workers, they will have to look for congruence between the individual's values and goals and the organization's values and goals. Values alignment and identification is central to every conceptualization of employee commitment.

The organization must exhibit a high level of commitment to its employees. If employees are concerned about losing their jobs, there is very little likelihood of high level of employees' commitment. If people are not given adequate resources, facilities and training they will not be likely to view the organization as being committed to them as well. 


\section{Bibliography}

[1] Ajila, C. and Awonusi, A. (2004). Influence of Rewards on Workers Performance in an Organization. Journal of Social Science. 8(1): Pp.7-12.

[2] Akintayo D.I. (2010). Work-Family Role Conflict and Organizational Commitment Among Industrial Workers in Nigeria. Journal of Psychology and Counselling. 2(1), Pp.1-8.

[3] Allen N.J. and Meyer J.P. (1990). The Measurement and Antecedents of Organizational Commitment: Re-examination of the Affective and Continuance Commitment Scales. Journal of Applied Psychology. 72, PP.638-642.

[4] Ali I., Rehman K., Ali S.I., Yousaf J. and Zia M. (2010). Corporate Social Responsibility Influences, Employee Commitment and Organizational Performance. African Journal of Business Management. 4(12), Pp.2796-2801.

[5] Avolio B.J., Zhu W., Koh W. amd Bhatia P. (2004). Transformational Leadership and Organizational Commitment: Mediating Role of Psychological Empowerment and Moderating Role of Structural Distance. Journal of Organizational Behaviour. 25, 951-968.

[6] Becker H.S. (1960). Notes on the Concept of Commitment. American Journal of Sociology. 66, Pp.32-40.

[7] Camilleri E. (2002). Some Antecedents of Organizational Commitment: Results from an Information Systems Public Sector Organization. Bank of Valletta Review. No. 25, pp.1-29.

[8] Dex S. and Smith C. (2001). Effects of Family-Friendly Policies on Employee Commitment: An Analysis of the Workplace Employee Relation Survey. The Judge Institute of Management Studies Working Paper. No. wp20/2001, PP.1-36.

[9] Habib A., Khursheed A. and Idrees A.S. (2010). Relationship Between Job Satisfaction, Job Performance Attitude Towards Work and Organizational Commitment. European Journal of Social Sciences. 18(2), Pp.257-267.

[10] Hunjra A.I, Ali M.A, Chani M.I, Khan H. and Rehman K. (2010). Employee Voice and Intent to Leave: An Empirical Evidence of Pakistani Banking Sector. African Journal of Business Management. 4(14), Pp.3056-3061.

[11] Khan M.R., Ziauddin, Jam F.A. and Ramay M.I. (2010. The Impacts of Organizational Commitment on Employee Job Performance. European Journal of Social Sciences. 15(3), Pp. 292-298

[12] Lo M., Ramayah T. and Min H.W. (2009). Leadership styles and Organizational Commitment: A Test on Malaysia Manufacturing Industry. African Journal of Marketing Management. 1(6), Pp.133

[13] Meyer P.J., and Allen J.N. (1984). Testing the Side-Bet Theory of Organizational Commitment: Some Methodological Considerations. Journal of Applied Psychology. 69, Pp.372-374

[14] Meyer J. and Allen N. (1991). A Three-Component Conceptualization of Organizational Commitment. Human Resources Management Review. 1, PP.61-89.

[15] Nowday R.T., Porter L.M. and Steers R.M. (1982). Employee Organizational Linkage. New York: Academic Press.

[16] Mowday R.T., Steers R.M. and Porter L.M. (1979). The Measurement of Organizational Commitment. Journal of Vocational Behaviour. 14, PP.224-247.

[17] Ongori H. (2007). A Review of the Literature on Employee Turnover. African Journal of Business Management. PP. 49-54.

[18] O'Reilly C.A. and Chatman J. (1986). Organizational Commitment and Psychological Attachment: The Effects of Compliance, Identification and Internalization on Prosocial Behaviour. Journal of Applied Psychology. 71, Pp. 492-499.

[19] Ponnu C.H. and Chuah C. C. (2010). Organizational Commitment, Organizational Justice and Employee Turnover in Malaysia. African Journal of Business Management. 4(13), Pp. 2676-2692.

[20] Porter L.W., Steers R.M., Mowday R.T. and Boulian P.V. (1974). Organizational Commitment, Job Satisfaction and Turnover Among Psychiatric Technicians. Journal of Applied Psychology. 59, Pp. 603-609.

[21] Shastric R.K., Shashi K.M. and Sinha A. (2010). Charismatic Leadership and Organizational Commitment: An Indian Perspective. African Journal of Business Management. 4(10), Pp. 1946-1953.

[22] Tumwesigye G. (2010). The Relationship Between Perceived Organizational Support and Turnover Intentions in a Developing Country: The Mediating Role of Organizational Commitment. African Journal of Business Management. 4(6), Pp. 942-952.

[23] Zahariah M.Z., Razanita I. and Erlane K.G. (2009). The Influence of Corporate Culture on Organizational Commitment: A Study on a Malaysian Listed Company. European Journal of Economics, Finance and Administrative Sciences. Issue 17, Pp.16-26.

[24] Zheng W., Sharan K. and Wei J. (2010). New Development of Organizational Commitment: A Critical Review (1960-2009). African Journal of Business Management. 4(1), Pp. 12-20.

[25] Ziauddin, Khan M.R., Jam F.A. and Hijazi S.T. (2010). The Impacts of Employees Job Stress on Organizational Commitment. European Journal of Social Sciences. 13(4), Pp. 617-622. 